\title{
HUBUNGAN ANTARA ASUPAN ENERGI, ASUPAN LEMAK, DAN OBESITAS PADA REMAJA SLTP DI KOTA YOGYAKARTA DAN DI KABUPATEN BANTUL
}

\author{
Ana Medawati Hamam Hadi², I D P Pramantara ${ }^{3}$
}

\begin{abstract}
Background: The prevalence of obesity in young children and adolescents has been increasing very dramatically during the last two decades, especially in big cities. High intake of energy and fat may have contributed to obesity.. Objective: To examine the relationship between energy intake, fat intake and obesity among adolescents.

Method: A Case Control Study was conducted in 2003. Subjects were Junior High School students, age 10-15 years, living in the city of Jogjakarta and Bantul Regency were included in the study. Data on nutrition intake were collected by using Food Frequency Questionnaires from 140 obese and 140 non obese junior high school students. Results: On average, the energy intake among cases and controls from the city of Jogjakarta were 2818,32 $\pm 618,05$ kcal/day and 2210,42 $\pm 329,81$ kcal/day respectively. Whereas total average of energy intake among cases and controls from Bantul were 2416,99 $\pm 673,52 \mathrm{kcal} /$ day and $1778,09 \pm 312,03 \mathrm{kcal} /$ day respectively. Obesity was significantly associated $(p<0.05)$ with total energy and fat intakes in both city Jogjakarta and Bantul.

Conclusion: Obesity was associated with total energy and fat intakes in Junior High School Students.
\end{abstract}

Key words: obesity, nutrient intake, Junior High School Student

\section{PENDAHULUAN}

Prevalensi obesitas meningkat secara tajam pada dekade akhir ini, sehingga menjadi kejadian luar biasa di beberapa negara. Di Eropa lebih dari setengah penduduk yang berusia 35-65 tahun mengalami overweight dan obesitas. Begitu pula di Amerika prevalensi obesitas meningkat yaitu dari $13 \%$ pada tahun 1960 menjadi 22,5\% pada tahun 1994 (1).

Di Asia, estimasi overweight oleh WHO pada anak prasekolah tahun 1995 sekitar 2,9\%, dengan 4,3\% di Asia bagian timur dan 2,4\% di Asia Tenggara (2). Kurang lebih 17,6 juta anak prasekolah di negara-negara berkembang mengalami overweight, $61 \%$ atau 10,6 juta di antaranya terdapat di Asia (3). Berdasarkan laporan tentang obesitas dari beberapa negara di Asia dan survei Kesehatan Sekolah di Singapura, menunjukkan bahwa prevalensi obesitas tahun 2000 adalah 10,8\% pada anak umur $6-7$ tahun, $14,7 \%$ pada umur $12-13$ tahun dan $13,1 \%$ pada umur 15-16 tahun (4).
Prevalensi obesitas di Indonesia menurut SUSENAS (Survei Sosial Ekonomi Nasional) menunjukkan peningkatan yaitu pada tahun 1989 sebesar $4,6 \%$ pada lelaki dan $5,9 \%$ pada perempuan, tahun 1992 menjadi $6,3 \%$ pada lelaki dan $8 \%$ pada perempuan. Di DKI Jakarta, prevalensi obesitas meningkat dengan bertambahnya umur. Pada umur 612 tahun ditemukan obesitas sekitar 4\%. Pada remaja umur 12-18 tahun ditemukan $6,2 \%$ dan pada umur 1718 tahun sekitar $11,4 \%$. Kasus obesitas pada remaja lebih banyak ditemukan pada perempuan $(10,2 \%)$ dibandingkan laki-laki (3,1\%). Prevalensi obesitas anak di sebuah sekolah dasar negeri di kawasan Jakarta Timur sebesar 27,5\% (5). Dari hasil penelitian di lapangan akhirakhir ini ditemukan bahwa prevalensi obesitas di Indonesia terutama di kota-kota besar berkisar 10\% hingga $18 \%(6,7)$. Prevalensi obesitas pada anak SMU di Kabupaten Tangerang sebanyak 5,01\%, laki-laki sebanyak $2,9 \%$ dan perempuan sebanyak $2,11 \%$ (8).

Indonesia saat ini sedang menghadapi masalah gizi ganda, yaitu masalah gizi kurang dan gizi lebih. Masalah gizi lebih baru muncul di permukaan pada tahun-tahun terakhir yaitu sejak Pembangunan Jangka Panjang I (PJP I) pada awal tahun 1990-an. Peningkatan pendapatan kelompok masyarakat tertentu terutama di perkotaan menyebabkan perubahan gaya hidup terutama dalam pola makan. Pola makan tradisional yang tadinya tinggi karbohidrat, tinggi serat, dan rendah lemak berubah ke pola makan baru yaitu rendah karbohidrat, rendah serat kasar, dan tinggi lemak sehingga terjadi pergeseran mutu makanan ke arah tidak seimbang. Perubahan pola makan dipercepat oleh makin kuatnya arus budaya asing yang disebabkan oleh kemajuan teknologi informasi dan globalisasi ekonomi. Di samping itu perbaikan ekonomi menyebabkan berkurangnya aktivitas fisik masyarakat tertentu. Perubahan pola makan dan aktivitas fisik ini berakibat semakin banyaknya penduduk golongan tertentu mengalami masalah gizi lebih berupa obesitas (9).

Terjadinya peningkatan kejadian obesitas di negara maju maupun di negara-negara berkembang

Fakultas Kedokteran Gigi Universitas Muhammadiyah Yogyakarta Magister Gizi dan Kesehatan UGM Yogyakarta

Bagian Penyakit Dalam RSUP Dr. Sardjito/Fakultas Kedokteran UGM Yogyakarta 
terutama pada golongan masyarakat tertentu memberi kesan bahwa faktor lingkungan yaitu pola makan dengan kalori berlebih di samping kurangnya aktivitas merupakan faktor yang dominan untuk terjadinya obesitas (10). Di negara-negara maju penanganan kasus gizi lebih telah menjadi prioritas utama untuk segera ditanggulangi supaya tidak timbul masalah baru yang meluas dan berkepanjangan. Hal ini mengingat masalah gizi lebih akan mempunyai dampak atau implikasi negatif terhadap terjadinya penyakit degeneratif seperti diabetes melitus, kanker, jantung koroner, ginjal, hipertensi, dan batu empedu (11)

Dari fenomena adanya masalah gizi lebih yang pada jangka panjang bisa menimbulkan masalah kesehatan ini, peneliti merasa perlu untuk mengetahui ada tidaknya hubungan antara asupan energi, asupan lemak, kontribusi lemak dari total energi dan obesitas pada remaja SLTP di Kota Yogyakarta dan Kabupaten Bantul, dua daerah dengan prevalensi obesitas yang berbeda (12).

Penelitian ini dilakukan untuk mengetahui adanya hubungan antara tingginya asupan energi dan obesitas pada remaja SLTP di Kota Yogyakarta dan Kabupaten Bantul, mengetahui adanya hubungan antara tingginya asupan lemak dan obesitas pada remaja SLTP di Kota Yogyakarta dan Kabupaten Bantul, dan mengetahui adanya hubungan antara besar kontribusi asupan lemak terhadap total energi dan obesitas pada remaja SLTP di Kota Yogyakarta dan Kabupaten Bantul.

\section{BAHAN DAN METODE}

\section{Rancangan dan Sampel Penelitian}

Untuk mencapai tujuan penelitian ini yakni melihat hubungan asupan energi, asupan lemak dan obesitas pada remaja SLTP di Kota Yogyakarta dan Kabupaten Bantul, digunakan penelitian observasional, dengan rancangan kasus-kontrol.

Pada penelitian ini jumlah minimal kasus yang diperlukan adalah 65 siswa. Kasus yang diambil di Kota Yogyakarta adalah sebanyak 75 remaja SLTP dan di Kabupaten Bantul sebanyak 65 remaja SLTP. Kasus adalah remaja SLTP yang menderita obesitas, yang diukur menggunakan indeks BB/TB dengan penilaian IMT dengan menggunakan kurva IMT percentile > 95\% dari Baku NCHS/CDC, berusia antara 10-15 tahun, berdomisili di Kota Yogyakarta dan Kabupaten Bantul dan bersedia diteliti dengan menanda-tangani informed consent. Setiap kasus dicarikan satu kontrol pasangannya yang disetarakan menurut jenis kelamin, umur, kelas dan sekolah kasus. Perbandingan antara kasus dan kontrol adalah 1:1, sehingga jumlah kontrol adalah 75 remaja SLTP di Kota Yogyakarta dan 65 remaja SLTP di Kabupaten Bantul yang tidak menderita obesitas serta memenuhi kriteria inklusi, yaitu berusia antara 10-15 tahun, bertempat tingal di Kota Yogyakarta dan Kabupaten Bantul dan bersedia menjadi responden penelitian dengan menanda-tangani informed consent.

\section{Lokasi dan Waktu Penelitian}

Penelitian ini dilaksanakan di 6 Sekolah Lanjutan Tingkat Pertama (SLTP) yang bertempat di Kota Yogyakarta dan 10 SLTP di Kabupaten Bantul, selama kurang lebih lima bulan, yaitu pada bulan September sampai bulan Desember 2003.

\section{Variabel Penelitian}

Variabel tergantung (dependent variable) dalam penelitian ini adalah obesitas, sedangkan variabel bebas (independent variable) yang dipelajari adalah asupan energi total, asupan lemak dan kontribusi lemak dari total energi. Adapun variabel luar penelitian yaitu tingkat sosial ekonomi, genetik dan aktivitas.

\section{Cara Pengumpulan Data}

Berat badan ditimbang menggunakan data tentang obesitas yang dikumpulkan dengan cara melakukan pengukuran antropometri yaitu mengukur berat badan dan tinggi badan. Berat badan ditimbang dengan menggunakan timbangan injak dengan tingkat ketelitian $0,01 \mathrm{~kg}$, sedangkan tinggi badan diukur dengan menggunakan alat pengukur Microtoise yang mempunyai kapasitas panjang $200 \mathrm{~cm}$ dengan ketelitian 0,1 cm. Data sosial ekonomi keluarga (tingkat pendidikan dan pendapatan dan jumlah anggota keluarga) dikumpulkan melalui metode wawancara kepada orang tua responden dengan mengunakan kuesioner. Data konsumsi zat gizi (asupan energi dan lemak) yang dilakukan dengan menggunakan food frequency questionnaire (FFQ) selama 3 bulan terakhir. Jumlah porsi dari ukuran rumah tangga (URT) dikonversikan ke dalam ukuran gram untuk dianalisis.

Semua data di lapangan dikumpulkan oleh tenaga enumerator dari lulusan Akademi Gizi Yogyakarta sebanyak 4 orang yang telah diseleksi dan dilatih sebelum pelaksanaan penelitian.

\section{Analisis Data}

Data yang telah terkumpul diolah dengan program komputer. Status obesitas ditentukan dengan indeks $\mathrm{BB} / \mathrm{TB}$ dengan penilaian IMT dengan menggunakan kurva IMT percentile > 95\% dari Baku NCHS/CDC (kurva CDC), sedangkan data konsumsi makanan 
diolah dengan nutri survey. Analisis dilakukan dengan menggunakan uji statistik t-test dan chi-square dan regresi logistik berganda.

\section{HASIL DAN BAHASAN \\ Karakteristik subjek penelitian}

Kasus dan kontrol dalam penelitian ini adalah remaja SLTP di Kota Yogyakarta dan Kabupaten Bantul. Jumlah sampel keseluruhan 280 siswa, yang terdiri dari 140 kasus ( 75 kasus dari Kota Yogyakarta dan 65 kasus dari Bantul) dan 140 kontrol (75 kontrol dari Kota Yogyakarta dan 65 kontrol dari Bantul). Hasil penelitian menunjukkan remaja laki-laki lebih tinggi yang mengalami obesitas yaitu 79 siswa $(65,4 \%)$ dibandingkan remaja perempuan yaitu 61 siswa $(43,6 \%)$

Distribusi remaja penderita obesitas berbeda menurut tingkat pendidikan orang tua. Diketahui bahwa pendidikan ayah dengan tingkat pendidikan menengah ke atas sebanyak 117 siswa $(83,6 \%)$ dan pada pendidikan ibu dengan tingkat pendidikan menengah ke atas sebesar 115 siswa (82,1\%), sedangkan tingkat pendidikan ayah menengah ke bawah 23 siswa $(16,4 \%)$ dan pada tingkat pendidikan ibu menengah ke bawah sebesar 25 siswa (17,9\%). Distribusi obesitas juga berbeda menurut pekerjaan ayah $(p<0,05)$, tetapi tidak berbeda menurut pekerjaan ibu (Tabel 1).

Distribusi penderita obesitas tidak berbeda menurut agama, suku dan pendapatan orang tua per bulan ( $p>0,05)$, tetapi menurut status gizi ayah maupun ibunya. Obesitas lebih banyak ditemukan $(p<0,05)$ pada remaja yang mempunyai ayah atau ibu penderita obesitas (Tabel 1).

Dalam penelitian ini dilaporkan bahwa hasil pengukuran antropometri remaja SLTP, rata-rata (mean) indeks massa tubuh (IMT) kelompok kasus sebesar 29,44 + 3,15 dan kelompok kontrol rata-rata IMTnya sebesar 18,18+3,22.

\section{Asupan Energi dan Asupan Lemak}

Dari hasil uji statistik dengan uji t-test tampak ada perbedaan yang signifikan antara kelompok kasus dan kelompok kontrol menurut asupan energi total, karbohidrat, lemak dan asupan protein $(p<0,05)$. Rata-rata asupan energi total di Kota Yogyakarta pada kelompok kasus sebesar 2818,32 \pm 499,38 kkal/hari sedangkan pada kelompok kontrol sebesar 2210,42 \pm $329,81 \mathrm{kkal} /$ hari. Rata-rata asupan energi total di Kabupaten Bantul adalah sebesar 2416,99 \pm 673,52 kkal/hari pada kelompok kasus sedangkan pada kelompok kontrol sebesar 1778,09 $\pm 312,03$ kkal/hari. Hasil analisis lebih lanjut tampak bahwa ada perbedaan yang signifikan rata-rata asupan energi total antara kasus dan kontrol pada remaja SLTP di Kota Yogyakarta dan di Kabupaten Bantul $(p<0,05)$ (Tabel 2).

Dari Tabel 2 ditunjukkan bahwa rata-rata asupan zat gizi pada kelompok kasus, baik di Kota Yogyakarta maupun di Kabupaten Bantul jauh lebih tinggi dibandingkan kelompok kontrol. Jumlah kalori yang dikonsumsi remaja SLTP berpengaruh terhadap kejadian obesitas. Kelebihan asupan energi merupakan kontributor penting terhadap kejadian obesitas di samping adanya kemajuan di bidang ilmu pengetahuan, teknologi dan ekonomi telah menciptakan suatu lingkungan dengan gaya hidup cenderung sedentary dan pola makan dengan makanan enak yang tinggi kalori dan tinggi lemak (13).

Manusia membutuhkan energi untuk mempertahankan hidup, menunjang pertumbuhan dan melakukan aktivitas fisik. Energi diperoleh dari karbohidrat, lemak, dan protein yang ada di dalam bahan makanan. Kandungan karbohidrat, lemak, dan protein suatu bahan makanan menentukan nilai energinya (9).

Untuk melihat hubungan asupan zat gizi dengan kejadian obesitas pada remaja SLTP, baik di Kota Yogyakarta maupun di Kabupaten Bantul dilakukan uji chi square. Dalam uji statistik tersebut dipakai ratarata total asupan zat gizi dari kelompok kontrol sebagai cut off, yaitu untuk energi total (2009,70 kkal/hari), karbohidrat (1097,61 kkal/hari), Lemak (578,94 kkal/ hari), dan protein (326,60 kkal/hari) (Tabel 3).

Dari Tabel 3 hasil uji chi square pada asupan energi total menunjukkan bahwa remaja SLTP di Kota Yogyakarta yang mengkonsumsi energi $\geq 2009,70$ kkal/ hari mempunyai kemungkinan untuk menjadi obesitas 26,9 kali lebih tinggi dibanding remaja SLTP yang mengkonsumsi energi < 2009,70 kkal/hari. Sedangkan di Kabupaten Bantul menunjukkan bahwa remaja SLTP di Kabupaten Bantul yang mengkonsumsi energi $\geq$ 2009,70 kkal/hari mempunyai peluang sebesar 8 kali lebih tinggi menjadi obesitas dibanding remaja SLTP yang mengkonsumsi energi < 2009,70 kkal/hari.

Remaja yang berasal dari Kota Yogyakarta yang mengkonsumsi lemak $\geq 578,94 \mathrm{kkal} /$ hari mempunyai kemungkinan lebih tinggi menjadi obesitas dibanding teman remajanya yang mengkonsumsi lemak < 578,94 $\mathrm{kkal} /$ hari $(\mathrm{OR}=11,19)$. Berbeda dengan remaja SLTP di Kabupaten Bantul, remaja SLTP yang mengkonsumsi lemak $\geq 578,94 \mathrm{kkal} /$ hari mempunyai peluang 5,70 kali lebih tinggi menjadi obesitas dibanding remaja SLTP yang mengkonsumsi lemak < $578,94 \mathrm{kkal} / \mathrm{hari}$. 
TABEL 1. Distribusi karakteristik responden

\begin{tabular}{|c|c|c|c|c|c|c|}
\hline \multirow{2}{*}{ Hiritit } & \multicolumn{2}{|c|}{ mukn } & \multicolumn{2}{|c|}{ That whring } & \multirow{2}{*}{$r^{i l}$} & \multirow{2}{*}{ a } \\
\hline & ก & 4 & I & 4 & & \\
\hline \multicolumn{7}{|l|}{ hath brith } \\
\hline 내바베 & $\mathrm{H}$ & Nㅐㅅㅏ & $\mathrm{m}$ & HII & 19:0 & Int \\
\hline Phytront| & 41 & 411 & tit & 41h & & \\
\hline Hridt & InI & InI & HE & $\ln$ & & \\
\hline \multicolumn{7}{|l|}{ 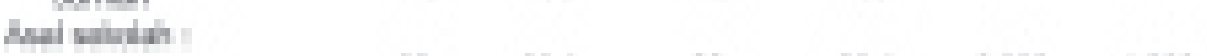 } \\
\hline 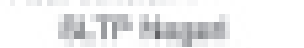 & 4 & HA & H & MA & Hath & thr \\
\hline MThain & H & 111 & tif & 111 & & \\
\hline hithi & 140 & ini & Hin & in & & \\
\hline \multicolumn{7}{|l|}{ 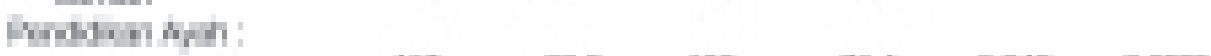 } \\
\hline if firtu & III & HE & wat & MA & 1.11 & 口ин \\
\hline " Then hith & in & $\mathrm{HA}$ & 4 & Mt & & \\
\hline smun & IHI & $\ln$ & its & $\ln$ & & \\
\hline \multicolumn{7}{|l|}{ Hobsin th: } \\
\hline of fort borh & 115 & 111 & II & 112 & 1112 & a माए \\
\hline " fard arta & A & TH & 4 & HI & & \\
\hline Horth & 140 & 16 & 145 & in & & \\
\hline \multicolumn{7}{|l|}{ Atmonsht } \\
\hline Ris Myrat & H & 41 & $\mathrm{rI}$ & Mit & มี & H mI" \\
\hline mati & II & WI & HI & HI & & \\
\hline mith & 141 & 117 & 145 & H1H & & \\
\hline \multicolumn{7}{|l|}{ 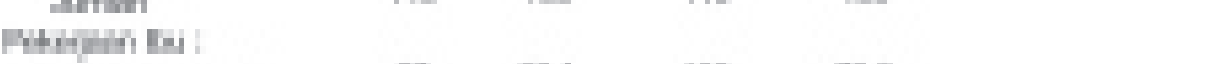 } \\
\hline Metri lownt & M & W1 & Hat & MI & & \\
\hline Phomi & 11 & IrII & Ir & MA & 네파 & เ \\
\hline Hint & InI & InI & HII & $\ln$ & & \\
\hline \multicolumn{7}{|l|}{ 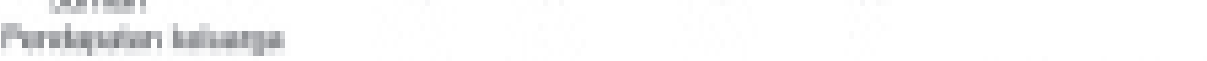 } \\
\hline \multicolumn{7}{|l|}{ p a mon } \\
\hline \multirow{3}{*}{ 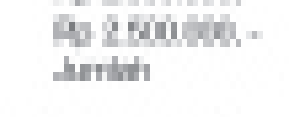 } & 4 & 41 & HI & nH & $T_{1}$ th & ด \\
\hline & $\mathrm{H}$ & 41 & in & 714 & & \\
\hline & thin & Iiti & Hit & $\ln$ & & \\
\hline \multicolumn{7}{|l|}{ Mhiendiph } \\
\hline Btrat & H & $4 i$ & it & hit & At, & nй \\
\hline 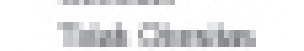 & 111 & 17! & 111 & 110 & & \\
\hline undt & 14 & ini & 14 & m & & \\
\hline \multicolumn{7}{|l|}{ Hhimin fa! } \\
\hline MH+. & 11 & II & 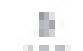 & IH & 패 & व जाए \\
\hline Fit when & 15 & Ant & 14 & Hit & & \\
\hline Hribh & 14t0 & 111 & 117 & 10 & & \\
\hline \multicolumn{7}{|l|}{ Fiti } \\
\hline then & $1 \mathrm{in}$ & ard & int & 4iti & It+4. & IIN \\
\hline Lun thw & 17 & 141 & 11 & 매 & & \\
\hline limint & thin & In & His & $\ln$ & & \\
\hline \multicolumn{7}{|l|}{ hin hidedar } \\
\hline hin thringi & h & W & in & 내 & $\tan$ & Int \\
\hline 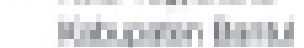 & $M$ & 4 & H & M & & \\
\hline Hrih & 140 & 17 & 111 & 16 & & \\
\hline
\end{tabular}

Keterangan: ${ }^{*}=$ Signifikan $(p<0,05)$ 
TABEL 2. Rata-rata asupan zat gizi berdasarkan kasus dan kontrol pada remaja SLTP di Kota Yogyakarta dan Kabupaten Bantul.

\begin{tabular}{|c|c|c|c|c|}
\hline $\begin{array}{c}\text { Aaupen Zat Ctu } \\
\text { (beuh) }\end{array}$ & $\begin{array}{c}\text { Kass } \\
\text { Moust SD }\end{array}$ & 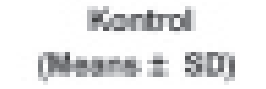 & 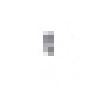 & $p$ \\
\hline \multicolumn{5}{|l|}{ Kod Tograth } \\
\hline Erag tots & 2ala $32+4$ an 33 & $27042=32$ 터 & BAT & equot \\
\hline Katalidat & $140424+15030$ & 1184, $15+21515$ & 900 & -bout \\
\hline Lemak & BdT7 \pm 20200 & $6+93 \pm 746$ & $\mathrm{~B}_{2} \cdot \mathrm{b}$ & etomis \\
\hline Proten & $46409 \pm 12311$ & $33,5 \mathrm{~T} \pm 91,53$ & $\mathrm{bin}$ & sbion: \\
\hline \multicolumn{5}{|l|}{ Kabupate- Butil } \\
\hline Engingl tot & $247500=5 T=12$ & 1TRBM + 317ng & anco & $\operatorname{spm} 1$ \\
\hline Katuhidat tod & $120 \mathrm{~s}+21 \omega$ & $97 \pi+1200$ & J5E & asti \\
\hline Leman tolal & $6004 \pm 2+1 B 1$ & $\sin x+13=3$ & 5,146 & Gonit \\
\hline Protin tal & $7859 \pm 6569$ & $2 \pi+4 \pm \pi n$ & 1Ebi & aboul \\
\hline \multicolumn{5}{|l|}{ TOTAL } \\
\hline Energil total & 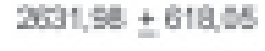 & 2ostĩ + 3b & 10,10 & ebọ \\
\hline Katuhida & Tats +275 & $1000 A^{\circ}+24,31$ & 7,54 & -4001' \\
\hline Lenat & TLEFS +733aA & $5794+15421$ & $T, 60$ & atumi \\
\hline Putsin & $41694 \pm 12 \beta 0$ & $56,00 \pm 960$ & 605 & anit \\
\hline
\end{tabular}

Keterangan: * $=$ Signifikan $(p<0,05)$

Rata-Rata Asupan Energi, Lemak, Karbohidrat dan Protein

Dari uji t-test dapat diketahui rata-rata kecukupan zat gizi terhadap AKG remaja SLTP, baik di Kota Yogyakarta maupun di Kabupaten Bantul yaitu kecukupan energi total, kecukupan karbohidrat, kecukupan lemak dan kecukupan protein (Tabel 4).

Rata-rata kecukupan asupan zat gizi yang dianjurkan, ternyata tingkat kecukupannya lebih tinggi pada kelompok kasus. Rata-rata asupan zat gizi remaja SLTP sudah sesuai dengan kebutuhan gizi yang dianjurkan, kecuali kecukupan karbohidrat di Kabupaten Bantul pada kelompok kontrol menunjukkan kurang dari kebutuhan gizinya. Di Kota Yogyakarta rata-rata kecukupan energi total terhadap AKG pada kelompok kasus yakni sebesar $(131,11+25,76) \%$ dan sebesar $(102,31+18,41) \%$ pada kelompok kontrol. Sedangkan remaja SLTP di Kabupaten Bantul rata-rata kecukupan energi total terhadap AKG pada kelompok kasus juga di atas angka kecukupan yang dianjurkan dan kecukupannya lebih tinggi dari kontrol, yakni sebesar $(113,74+32,73) \%$ dan sebesar $(83,39+16,34) \%$ pada kelompok kontrol. Hasil uji statistik menunjukkan ada perbedaan yang bermakna antara rata-rata kecukupan energi total terhadap AKG dengan kejadian obesitas $(p<0,05)$.
Dari Tabel 4 pada penelitian ini secara statistik terlihat rata-rata kecukupan lemak terhadap AKG remaja SLTP di Kota Yogyakarta dan di Kabupaten Bantul baik pada kelompok kasus maupun kelompok kontrol menunjukkan ada perbedaan yang bermakna $(p<0,05)$ dan berada di atas angka kebutuhan gizi yang dianjurkan. Di Kota Yogyakarta rata-rata kecukupan lemak terhadap AKG yakni sebesar $(151,06+40,12)$ pada kasus dan sebesar $(117,35+30,60)$ pada kelompok kontrol. Sedangkan remaja SLTP di Kabupaten Bantul rata-rata kecukupan lemak terhadap AKG pada kelompok kasus juga di atas angka kecukupan yang dianjurkan dan lebih tinggi dari kontrol, yakni sebesar $(128,59+46,27)$ dan sebesar $(94,55$ $+26,23)$ pada kelompok kontrol.

Berdasarkan hasil FFQ yang kemudian dilakukan perhitungan kecukupan yaitu membandingkan jumlah masing-masing rata-rata asupan zat gizi dengan kecukupannya (dalam bentuk persen) dan skala ordinal ( $\geq 100$ AKG dan < 100\% AKG). Kecukupan berisiko menjadi obesitas bila kecukupan energi total setiap harinya $\geq 100 \%$ AKG. Dan bila kecukupan energi total setiap harinya < 100\% AKG berarti kurang dari kebutuhan gizi yang dianjurkan. Hasil analisis dengan uji chi square, terlihat bahwa kecukupan zat gizinya menunjukkan ada perbedaan yang bermakna antara 
TABEL 3. Hubungan asupan zat gizi pada remaja SLTP dengan kejadian obesitas berdasarkan kasus dan kontrol pada remaja SLTP Kota Yogyakarta dan Kabupaten Bantul

\begin{tabular}{|c|c|c|c|c|c|c|c|}
\hline \multirow{2}{*}{ 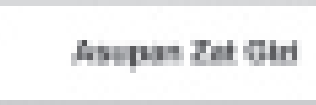 } & \multicolumn{2}{|c|}{ Кй } & \multicolumn{2}{|c|}{ Fumbi } & \multirow{2}{*}{ 메 } & \multirow{2}{*}{ HAr } & \multirow{2}{*}{ 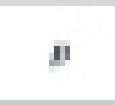 } \\
\hline & n & 4 & - & 4 & & & \\
\hline \multicolumn{8}{|l|}{ Foin Moduti } \\
\hline andowh & $\mathrm{M}$ & 447 & hit & Ha & IH & Mh shits & ABmi \\
\hline - Marhitr & 1 & 11 & I & Mit & & & \\
\hline Jurih & H & 1부 & 굴 & in่ & & & \\
\hline \multicolumn{8}{|l|}{ 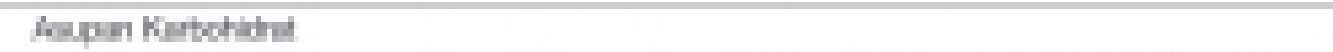 } \\
\hline in How hith & 74 & 41 & BI & $\mathrm{mi}$ & $\mathrm{MTP}$ & 4.14-MMI & mind \\
\hline 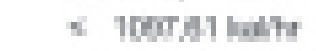 & 1 & 11 & $\boldsymbol{M}$ & PI & & & \\
\hline Hoth & 71 & 100 & $\mathrm{~T}$ & 100 & & & \\
\hline \multicolumn{8}{|l|}{ haqun lonth } \\
\hline if MBAth & ri & 417 & sii & Hit $y$ & 11.14 & 1нн-1241 & - Hพ⿴囗十 \\
\hline - smithdt & 4 & hI & 24 & 년 & & & \\
\hline hatili & $\mathrm{ni}$ & ํำ & $\mathrm{hi}$ & 내 & & & \\
\hline \multicolumn{8}{|l|}{ Ausun Grotin } \\
\hline is Gi, whith & 74 & 47 & 4 & 643 & Hin & 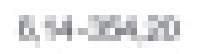 & $\operatorname{mon} 1^{\prime}$ \\
\hline intholt & 1 & 11 & $M$ & 317 & & & \\
\hline Juth & 7 & 10 & $\mathrm{TH}$ & 10 & & & \\
\hline \multicolumn{8}{|l|}{ 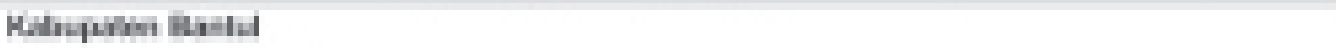 } \\
\hline \multicolumn{8}{|l|}{ Magn Furd thy } \\
\hline in minthit & $M$ & $\mathrm{~ms}$ & If & 215 & $\mathrm{ax}$ & MA.17m & s.Mp' \\
\hline - Mry m thy & 4 & 77 & 4 & 74 & & & \\
\hline Huth & H & $\ln$ & $\mathrm{m}$ & $\ln$ & & & \\
\hline \multicolumn{8}{|l|}{ hapn Hutution } \\
\hline a won bath & $\mathbf{n}$ & +1is & $y$ & sil & $\mathrm{t}, \mathrm{FH}$ & by-1H & Bquit \\
\hline - IOTHAlhtr & II & Mit & 하 & His & & & \\
\hline Hoth & w & 100 & 보 & 10i & & & \\
\hline \multicolumn{8}{|l|}{ Amsim Leth } \\
\hline is Mpath & 41 & 611 & 19 & 71 & ArD & 1M.127 & mopit" \\
\hline \multirow[t]{2}{*}{ a जmolkh } & $M$ & Ho & 5 & 70 & & & \\
\hline & 6 & $\ln$ & 6y & In & & & \\
\hline \multicolumn{8}{|l|}{ haqum Fouth } \\
\hline a Mon hals & 11 & 117 & Ia & ти Б & 4 & - M-1M & ub" \\
\hline - Mwhlth & 11 & os & Al & HE h & & & \\
\hline Hirtili & Hit & 내 & H & witi & & & \\
\hline
\end{tabular}

Keterangan: * = signifikan $(\mathrm{p}<0,05)$

OR= Odds ratio, $95 \% \mathrm{Cl}=$ Confidence Interval $95 \%$ 
TABEL 4. Rata-rata kecukupan asupan zat gizi terhadap AKG dengan kejadian obesitas berdasarkan kasus kontrol pada remaja SLTP di Kota Yogyakarta dan Kabupaten Bantul

\begin{tabular}{|c|c|c|c|c|}
\hline $\begin{array}{c}\text { Variabel } \\
(\% \text { AKG per hari) }\end{array}$ & $\begin{array}{c}\text { Kasus } \\
\text { (Means } \pm \text { SD) }\end{array}$ & $\begin{array}{c}\text { Kontrol } \\
\text { (Means } \pm \text { SD) }\end{array}$ & $\mathbf{t}$ & $p$ \\
\hline \multicolumn{5}{|l|}{ Kota Yogyakarta } \\
\hline Energi Total & $131,11 \pm 25,76$ & $102,31 \pm 18,41$ & 7,877 & $<0,001^{*}$ \\
\hline Karbohidrat & $106,59 \pm 16,92$ & $84,11 \pm 16,40$ & 8,261 & $<0,001^{\star}$ \\
\hline Lemak & $151,06 \pm 40,12$ & $117,35 \pm 30,60$ & 5,786 & $<0,001^{\star}$ \\
\hline Protein & $207,85 \pm 53,86$ & $161,02 \pm 49,42$ & 5,548 & $<0,001^{*}$ \\
\hline \multicolumn{5}{|l|}{ Kabupaten Bantul } \\
\hline Energi total & $113,74 \pm 32,73$ & $83,39 \pm 16,34$ & 6,689 & $<0,001^{\star}$ \\
\hline Karbohidrat & $81,69 \pm 15,68$ & $72,12 \pm 14,54$ & 3,609 & $<0,001^{\star}$ \\
\hline Lemak & $128,59 \pm 46,27$ & $94,55 \pm 26,23$ & 5,160 & $<0,001^{*}$ \\
\hline Protein & $140,43 \pm 39,28$ & $116,31 \pm 39,46$ & 3,493 & $0,001^{*}$ \\
\hline \multicolumn{5}{|l|}{ TOTAL } \\
\hline Energi total & $123,05 \pm 30,37$ & $93,53 \pm 19,83$ & 9,631 & $<0,001^{*}$ \\
\hline Karbohidrat & $95,03+20,52$ & $78,54+16,63$ & 7,386 & $<0,001^{\star}$ \\
\hline Lemak & $140,63 \pm 44,38$ & $106,76 \pm 30,75$ & 7,422 & $<0,001^{*}$ \\
\hline Protein & $176,55 \pm 58,25$ & $140,26 \pm 50,18$ & 5,585 & $<0,001^{\star}$ \\
\hline $\begin{array}{l}{ }^{*}=S \\
A K G\end{array}$ & & & & \\
\hline
\end{tabular}

kasus dan kontrol, baik di Kota Yogyakarta dan Kabupaten Bantul $(p<0,05)$ (Tabel 5).

Tetapi berbeda dengan hasil uji chi-square kontribusi lemak terhadap total energi yang tidak bermakna, hubungan antara kecukupan lemak terhadap AKG dengan kejadian obesitas antara kasus dan kontrol menunjukkan ada perbedaan yang bermakna pada remaja SLTP baik di Kota Yogyakarta maupun di Kabupaten Bantul $(p<0,05)$. Di Kota Yogyakarta remaja SLTP yang rata-rata kecukupan lemak setiap harinya $>100 \%$ AKG pada kasus ada sebanyak 71 siswa $(94,7 \%)$ dan pada kontrol sebanyak 50 siswa $(66,7 \%)$, sedangkan rata-rata kecukupan lemak < $100 \%$ AKG pada kasus sebanyak 4 siswa (5,3\%) dan pada kontrol sebanyak 25 siswa (33,3\%). Dari hasil uji statistik menunjukkan bahwa remaja SLTP di Kota Yogyakarta yang rata-rata kecukupan lemak setiap harinya $>100 \%$ AKG mempunyai kemungkinan untuk menjadi obesitas sebesar 8,87 kali lebih tinggi dibanding remaja SLTP yang kecukupan lemak setiap harinya $<100 \%$ AKG.

Sedangkan di Kabupaten Bantul hasil analisis remaja SLTP yang rata-rata kecukupan lemak setiap harinya $>100 \%$ AKG pada kasus sebanyak 47 siswa (72,3\%) dan pada kontrol sebanyak 27 siswa (41,5\%), dan remaja SLTP yang rata-rata kecukupan lemak setiap harinya $<100 \%$ AKG pada kasus ada sebanyak 18 siswa $(27,7 \%)$ dan pada kontrol sebanyak 38 siswa (58,5\%). Dari hasil uji statistik menunjukkan bahwa remaja SLTP di Kabupaten Bantul yang rata-rata kecukupan lemak setiap harinya $>100 \%$ AKG mempunyai peluang atau kemungkinan untuk menjadi obesitas sebesar 3,67 kali lebih tinggi dibanding menunjukkan remaja SLTP di Kabupaten Bantul yang rata-rata kecukupan lemak setiap harinya $<100 \%$ AKG.

\section{Analisis Regresi Logistik}

Untuk melihat faktor-faktor apa saja yang diduga sebagai pencetus terjadinya obesitas pada remaja SLTP pada asupan zat gizi saja, dilakukan uji regresi logistik dan menunjukkan hasil yang signifikan $(p<0,05)$. Hasil analisis regresi logistik menunjukkan semakin tinggi asupan karbohidrat, asupan lemak dan asupan protein, semakin tinggi kejadian obesitas pada remaja SLTP di Kota Yogyakarta. sedangkan di Kabupaten Bantul yang menyebabkan tingginya kejadian obesitas remaja SLTP adalah tingginya asupan energi total dan asupan karbohidrat (Tabel 6).

Di Kota Yogyakarta asupan karbohidrat pada remaja SLTP yang mengkonsumsi karbohidrat > 1097,61 kkal/hari mempunyai kemungkinan untuk terjadinya obesitas sebesar 31,03 kali lebih tinggi dibandingkan remaja SLTP yang mengkonsumsi karbohidrat < 1097,61 kkal/hari. Remaja SLTP yang mengkonsumsi lemak $>578,94 \mathrm{kal} /$ hari mempunyai kemungkinan menjadi obesitas sebesar 4,52 kali lebih tinggi dibandingkan yang mengkonsumsi < 578,94 kkal/ hari. Dan untuk remaja SLTP yang mengkonsumsi pro- 
TABEL 5. Hubungan kecukupan energi total terhadap AKG dan kecukupan lemak terhadap AKG dengan kejadian obesitas berdasarkan kasus dan kontrol pada remaja SLTP di Kota Yogyakarta dan Kabupaten Bantul

\begin{tabular}{|c|c|c|c|c|c|c|c|}
\hline \multirow{2}{*}{ 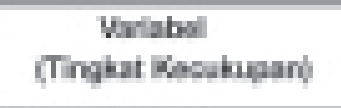 } & \multicolumn{2}{|c|}{ Kanen } & \multicolumn{2}{|c|}{ Rorlud } & \multirow{2}{*}{ an } & \multirow{2}{*}{ Pri cl } & \multirow{2}{*}{ e } \\
\hline & $\mathrm{n}$ & 4 & i & 4 & & & \\
\hline \multicolumn{8}{|l|}{ Fota forraterta } \\
\hline \multicolumn{8}{|l|}{ Erapi tud butip ans } \\
\hline twoth & $r$ & HI & II & 915 & 16230 & Hath-4y & $401 \%$ \\
\hline$=10 \mathrm{~m}$ & 4 & 53 & $\mathbf{y}$ & 51t & & & \\
\hline Heist: & $\pi$ & 10 & $\pi$ & $\operatorname{lin}$ & & & \\
\hline \multicolumn{8}{|l|}{ 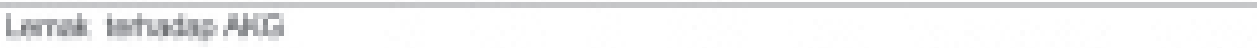 } \\
\hline is $150 h$ & $\mathrm{Tt}$ & 40 & $\boldsymbol{\theta}$ & H.J & ABn & 24tนMb & twot' \\
\hline$=10 \mathrm{~s}$ & 4 & $\mathbf{6}$ & bi & 34 & & & \\
\hline durtat & $\mathrm{T}$ & 100 & $\mathrm{n}$ & 10 & & & \\
\hline \multicolumn{8}{|l|}{ Hib.pown Butal } \\
\hline \multicolumn{8}{|l|}{ 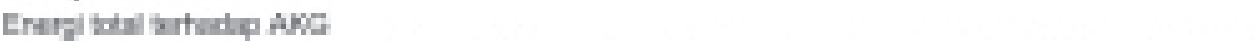 } \\
\hline anth & 4 & aIs & 13 & 200 & 140 & 2014-14 & -[Dopt' \\
\hline a rogh & M & 115 & $m$ & Mi & & & \\
\hline Mrihk & Ei & 10 & Ai & $\operatorname{in}$ & & & \\
\hline \multicolumn{8}{|l|}{ Lemal ishodiparif } \\
\hline ison & $\mathrm{si}$ & 73 & 27 & atif & $1 \mathrm{Ami}$ & 174-7GS & ACH" \\
\hline$=1 \mathrm{tan}$ & 19 & 23 & 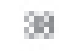 & AS & & & \\
\hline Jutit & $\mathbf{m}$ & 10 & $\mathbf{m}$ & 10 & & & \\
\hline \multicolumn{8}{|l|}{ TOFAL } \\
\hline \multicolumn{8}{|l|}{ 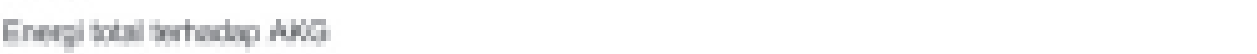 } \\
\hline$y \quad 1 x y$ & 111 & $\mathrm{~m} 3$ & 5 & nt & Amo & 4, to -11,70s & stopis \\
\hline - $150 \mathrm{~h}$ & w & wit & $\boldsymbol{H}$ & 45 & & & \\
\hline Mriat & 140 & 10 & 145 & titi & & & \\
\hline \multicolumn{8}{|l|}{ Imot minth has } \\
\hline tath & IIE & als & $\pi$ & 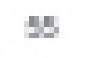 & 430 & $2,47-713$ & -0iont \\
\hline+100 & $\boldsymbol{z}$ & 157 & 6 & 45 & & & \\
\hline Wriat & 145 & 10 & 145 & 10 & & & \\
\hline $\begin{array}{ll}\text { Keterangan: } & { }^{*}=\text { Signifika } \\
& \text { OR }=\text { Odds } r \\
& \text { ETP\% Eners }\end{array}$ & $\begin{array}{l}<0,0 \\
\text { otal } \\
\text { otal }\end{array}$ & $\mathrm{I}=\mathrm{C}$ & d & terval & & & \\
\hline
\end{tabular}

tein > 326,60 kkal/hari mempunyai kemungkinan menjadi obesitas sebesar 28,47 kali lebih tinggi dibanding yang mengkonsumsi protein $<326,60 \mathrm{kkal} /$ hari.

Sedangkan di kabupaten Bantul remaja yang asupan energi totalnya $>2009,70 \mathrm{kal} /$ hari mempunyai kemungkinan untuk menjadi obesitas sebesar 14,81 kali lebih tinggi dibandingkan yang asupan energi totalnya $<2009,70 \mathrm{kal} /$ hari. Biasanya makanan yang enak cenderung mengandung protein dan lemak yang tinggi, sehingga pada akhirnya akan berdampak pada konsumsi energi yang berasal dari lemak serta protein yang tinggi (14).

Selanjutnya dilakukan kembali analisis regresi logistik, tetapi dengan memasukkan semua variabel yang mempunyai nilai signifikan $(p<0,05)$ termasuk dari karakteristik subjek penelitian dalam uji multivariat, untuk melihat faktor-faktor yang diduga paling berperan sebagai pencetus terjadinya obesitas dalam penelitian ini seperti terlihat pada Tabel 6. Variabel yang dimasukkan adalah asupan energi total, asupan karbohidrat, asupan lemak, asupan protein, pendidikan bapak, pendidikan ibu, pekerjaan bapak, status gizi bapak dan satus gizi ibu.

Hasil analisis multivariat menunjukkan bahwa faktor-faktor yang diduga paling berperan sebagai pencetus terjadinya obesitas di Kota Yogyakarta adalah status gizi bapak dan asupan lemak, dan di Kabupaten Bantul adalah Asupan energi total dan asupan karbohidrat (Tabel 7). 
TABEL 6. Faktor-faktor yang berhubungan dengan kejadian obesitas remaja SLTP di Kota Yogyakarta dan Kabupaten Bantul

\begin{tabular}{|c|c|c|c|c|}
\hline Faktor-faktor & $\mathbf{B}$ & OR & $95 \% \mathrm{Cl}$ & $p$ \\
\hline \multicolumn{5}{|l|}{$\begin{array}{l}\text { Kota Yogyakarta } \\
\text { Asupan Karbohidrat (kkal/hr) }\end{array}$} \\
\hline$\geq 1097,61$ & 3,435 & 31,03 & $2,58-313,58$ & 0,014 \\
\hline$<1097,61$ & & & & \\
\hline \multicolumn{5}{|l|}{ Asupan Lemak (kkalhr) } \\
\hline$\geq 578,94$ & 1,508 & 4,52 & $1,26-16,21$ & 0,021 \\
\hline$<578,94$ & & & & \\
\hline \multicolumn{5}{|l|}{ Asupan Protein (kal/hr) } \\
\hline$\geq 326.60$ & 3,349 & 28,47 & $2,03-473,57$ & 0,006 \\
\hline \multicolumn{5}{|l|}{$<326,60$} \\
\hline \multicolumn{5}{|l|}{ Kabupaten Bantul } \\
\hline Energi Total (kkalhr) & 2,695 & 14,81 & $2,85-77,00$ & $0,001^{*}$ \\
\hline \multicolumn{5}{|l|}{$\geq 2009,69$} \\
\hline \multicolumn{5}{|l|}{$<2009,69$} \\
\hline \multicolumn{5}{|l|}{ Asupan Karbohidrat (kkal/hr) } \\
\hline$\geq 1097,61$ & $-1,816$ & 0,34 & $0,34-0,77$ & 0,022 \\
\hline$<1097,61$ & & & & \\
\hline
\end{tabular}

Keterangan: $\quad *$ Signifikan $(\mathrm{p}<0,05)$

$\mathrm{OR}=$ Odds ratio, $95 \% \mathrm{Cl}=$ Confidence Interval $95 \%$

TABEL 7. Faktor-faktor yang berhubungan dengan kejadian obesitas remaja SLTP di Kota Yogyakarta dan Kabupaten Bantul

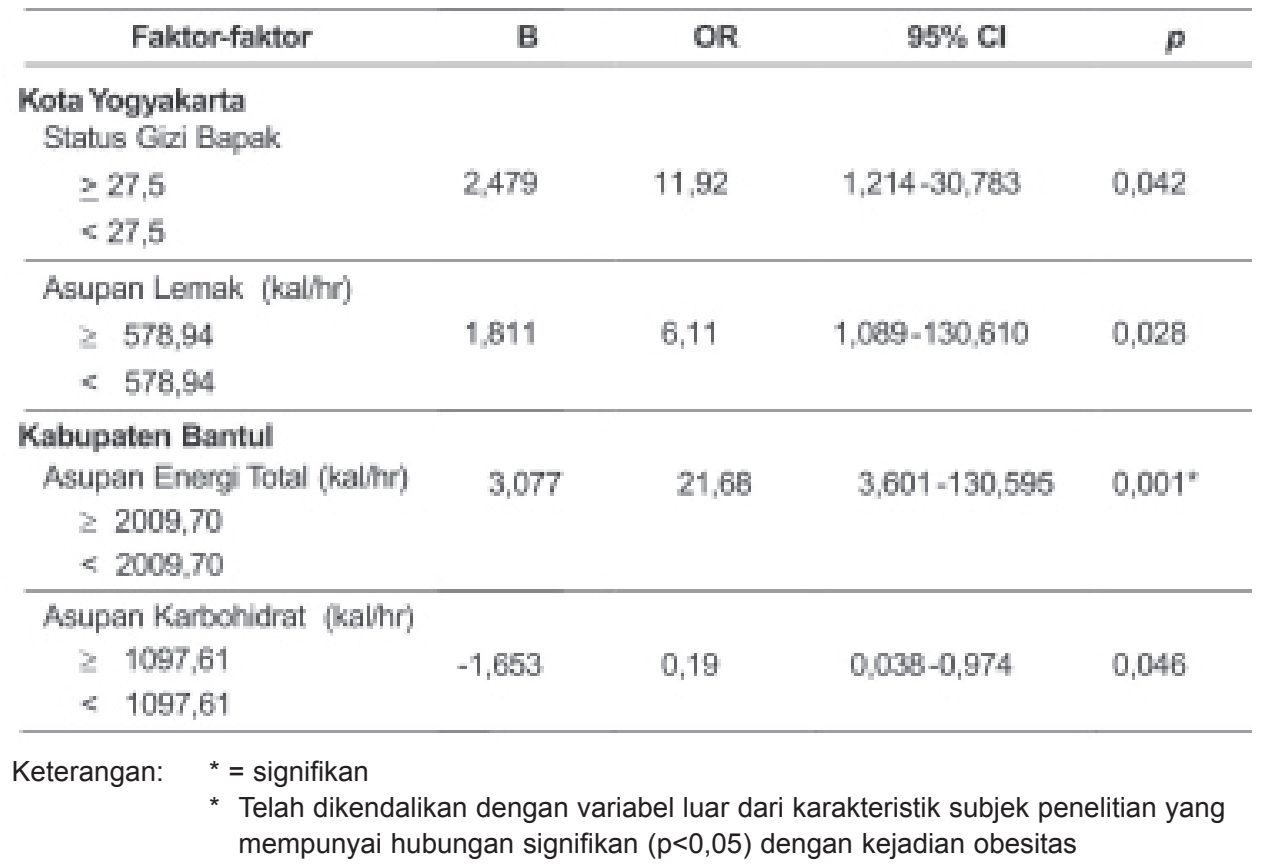

Hasil uji statistik di Kota Yogyakarta menunjukkan status gizi bapak mempunyai kemungkinan terjadinya obesitas pada remaja SLTP $(O R=11,92)$. Ini menunjukkan semakin tinggi status obesitas ayah maka semakin tinggi kejadian obesitas pada anaknya. Herini (15) juga melaporkan bahwa anak yang salah satu orang tuanya gemuk mempunyai resiko $40-50 \%$ untuk menjadi gemuk. Apabila kedua orang tuanya gemuk kemungkinan untuk menjadi gemuk sebesar $80 \%$. Penelitian pada remaja Sekolah Menengah umum (SMU) di Tangerang, melaporkan remaja SMU yang ibunya menderita obesitas mempunyai kemungkinan 2,69 kali lebih besar menjadi obesitas dibandingkan remaja SMU yang ibunya tidak obesitas. Sedangkan 
remaja SMU yang ayahnya menderita obesitas mempunyai kemungkinan 1,99 kali menjadi obesitas dibandingikan remaja SMU yang ayahnya tidak obesitas (8).

Hal ini sesuai Davies, dkk (10) yang melaporkan bahwa terjadinya peningkatan kejadian obesitas di negara maju maupun negara-negara berkembang terutama pada golongan masyarakat tertentu memberi kesan bahwa faktor lingkungan yaitu pola makan dengan kalori berlebih di samping kurangnya aktivitas merupakan faktor yang dominan untuk terjadinya obesitas. Karena Soedibyo (16) melaporkan bahwa obesitas disebabkan oleh masukan energi yang melebihi kebutuhan sehari-hari untuk memelihara dan memulihkan kesehatan, proses tumbuh kembang dan melakukan kegiatan aktivitas atau aktivitas jasmani, yang berlangsung secara terus menerus dalam jangka waktu yang cukup lama (positif energy balance). Faktor makanan ini merupakan faktor yang terpenting untuk terjadinya kegemukan baik sebagai penyebab tunggal maupun bergabung dengan penyakit-penyakit lain.

\section{KESIMPULAN DAN SARAN}

Penelitian ini menghasilkan tiga kesimpulan: Pertama Semakin tinggi asupan energi semakin tinggi kemungkinan untuk terjadinya obesitas pada remaja SLTP di Kota Yogyakarta dan Kabupaten Bantul. Kedua semakin tinggi asupan lemak semakin tinggi kemungkinan untuk terjadinya obesitas pada remaja SLTP di Kota Yogyakarta dan Kabupaten Bantul. Ketiga tidak ada hubungan kontribusi lemak terhadap total energi untuk terjadinya obesitas pada remaja SLTP di Kota Yogyakarta dan Kabupaten Bantul. Tetapi Semakin tinggi kontribusi lemak terhadap AKG semakin tinggi kemungkinan untuk terjadinya obesitas di Kota Yogyakarta maupun di Kabupaten Bantul.

Berdasarkan kesimpulan di atas, ada beberapa saran yang bisa dipergunakan untuk mencegah peningkatan prevalensi obesitas di Kota Yogyakarta dan Kabupaten Bantul adalah sebagai berikut:

1. Perlu diberikan pendidikan ilmu gizi dan kesehatan bagi remaja SLTP khususnya dan masyarakat umumnya tentang manfaat, pemilihan jenis makanan, jumlah dan kualitas makanan yang sesuai dengan kebutuhan gizi remaja dalam penanggulangan dan pencegahan obesitas.

2. Peranan ahli gizi diperlukan dalam konsultasi gizi dan penyuluhan bagi remaja SLTP yang obesitas maupun orang tuanya melalui program Usaha Kesehatan sekolah (UKS) agar mengetahui bahaya dampak obesitas yang terjadi dan cara penanganan obesitas yang benar, dengan motivasi tinggi memperhatikan nilai kalori makanannya berdasarkan pengetahuan kebutuhan gizi dan status gizinya. Ditindak lanjuti dengan pengawasan dan penyediaan jajanan yang sehat di kantin sekolah.

3. Bagi orang tua dan masyarakat harus mewaspadai apabila anaknya mengalami obesitas, karena dapat berisiko tinggi menderita penyakit, seperti jantung koroner, DM dan sebagainya.

4. Bagi peneliti yang ingin melakukan penelitian sejenis atau mengembangkan penelitian lebih lanjut tentang obesitas lebih mendalam, sehingga dapat mengungkap pengaruh faktor-faktor risiko yang lain dari obesitas seperti genetik dan kelainan hormonal.

\section{RUJUKAN}

1. Wolf AM, Colditz GA. Social and Economic Effect of Body Weight in The United States, Am J Clin Nutr 1996:106;1101.

2. De Onis M, Blossner M. Prevalence and Trends of Overweight among Preschool Children in Developing Countries. Am J Clin Nutr 2000:72;10329.

3. Tee ES. Obesity in Asia: Prevalence and Issues in Assesment Methodologies. Asia Pasific J Clin Nutr, 2002:11(3);694-701.

4. Loke KY. Consequences of Childhood and Adolescent Obesity. Asia Pacific J Clin Nutr 2002:11(3);S702-4.

5. Rusli DS. Obesity in Child Hood: Patogenesis and Management. Dalam Adskandar et al. Naskah Lengkap National Obesity symposium I. Editor: Tjokroprawiro A, dkk., Surabaya; 2002.

6. Ismail D, Herini ES, Hagung P, Sadjimin T. Fast food Consumption and Obesity: Relationship among Elementary School Student in Yogyakarta. Paediatric Indonesia 1999:39;127-33.

7. Padmiari IEA, Hadi H. Konsumsi Fast Food sebagai Faktor Risiko Obesitas pada Anak SD, Majalah Kedokteran Medika 2003:29(3).

8. Suhendro. Fast Food sebagai Faktor Risiko Terjadinya Obesitas pada Remaja Siswa-siswa SMU di Kota Tangerang Propinsi Banten [tesis]. Yogyakarta: Universitas Gadjah Mada; 2003.

9. Almatsier S. Prinsip Dasar IImu Gizi. Jakarta: PT. Gramedia; 2002.

10. Davies PSW, Gregory J, and White A. (1995) Physical Activity and Body Fatness in Pre-school Children. Int $\mathrm{J}$ Obes Relat Metab Disord 1995:19:5-10. 
11. Departemen Kesehatan RI. Rencana Pembangunan Kesehatan Menuju Indonesia Sehat 2010. Jakarta: Depkes RI; 1996.

12. Mahdiah. Prevalensi Obesitas dan Hubungan Konsumsi Fast Food dengan Kejadian Obesitas pada Remaja SLTP Kota dan Desa di Daerah Istimewa Yogyakarta [tesis]. Yogyakarta: Universitas Gadjah Mada; 2004

13. Yap DM, Yian BT, Kai SC, Deurenberg P, Stavveren VAW. Manifestastion of Cardiovascular Risk at Low Levels of Body Mass Index and Waist to Hip Ratio in Singaporean Chinese. Asia Pacific J Clin nutr 1999:8(3);177-83.
14. Hardiansyah dan Martianto D. Menaksir Kecukupan Energi dan Protein serta Penilaian Mutu Gizi Konsumsi Pangan Wirasari. Jakarta; 1989.

15. Herini ES. Karakteristik Keluarga dengan Anak Obesitas. Berita Kedokteran Masyarakat 1999:15(2).

16. Soedibyo S. Kegemukan Obesitas dan Penyakit Regeneratif: Epidemiologi dan Strategi Penanggulangannya, Widyakarya Nasional Pangan dan Gizi. Jakarta: LIPI; 1996. 